\title{
ANALISIS PERTUMBUHAN KESEMPATAN KERJA SEKTOR PERTANIAN DI KABUPATEN BARITO SELATAN.
}

\author{
${ }^{1}$ Frilia Christin, ${ }^{2}$ Betrixia Barbara, ${ }^{3}$ Evi Feronika Elbaar \\ ${ }^{1}$ Alumnus Program Studi Agribisnis Fakultas Pertanian Universitas Palangka Raya \\ ${ }^{2,3}$ Staf Pengajar Program Studi Agribisnis Fakultas Pertanian Universitas Palangka Raya
}

\begin{abstract}
ABSTRAK
Penelitian ini memiliki tujuan mengetahui pertumbuhan kesempatan kerja di sektor pertanian di Kabupaten Barito Selatan. Data yang digunakan adalah data sekunder. Untuk menjawab tujuan digunakan shift share. Hasil penelitian menunjukkan bahwa pertumbuhan kesempatan kerja sektor pertanian Kabupaten Barito Selatan tahun 20112015 menunjukkan hasil sebesar -8.481 atau $-22 \%$. Hal ini berarti terjadi penurunan kesempatan kerja di sektor pertanian sebesar 8.481 jiwa dan masuk ke dalam kelompok lamban

Kata kunci : Tenaga Kerja, shift share
\end{abstract}

\section{ABSTRACT}

The purpose of this study are know the growth of employment opportunities of Agricultural Sector In South Barito Regency. The data used in this study is secondary data. To answer the purpose used shift share. The result of this Study indicates that the growth of employment of agricultural sector in South Barito Regency in 2011-2015 shows the result of -8.481 or $-22 \%$. It means that there is a decrease in employment opportunities in the agricultural sector of 8,481 People and classified as a slow group.

Keywords:Labor, shift share

\section{PENDAHULUAN}

Indonesia dengan sebagian besar wilayah diperuntukkan sebagai lahan pertanian menjadikan sebagian besar sumber mata pencarian penduduknya berada pada sektor pertanian. Sektor pertanian difungsikan sebagai basis atau landasan pembangunan ekonomi. Sehingga pemerintah dituntut agar dapat memberikan kebijakan untuk mengatasi berbagai persoalan termasuk masalah kesejahteraan bangsa (Faqih, 2009).

Sumberdaya manusia adalah salah satu unsur utama atau sebagai pelaku pembangunan ekonomi dan pembangunan pada bidang lainnya. Jumlah penduduk dapat berdampak baik bagi keberhasilan pembangunan dan dapat menjadi beban bagi suatu pembangunan. Apabila jumlah suatu penduduk lebih besar daripada lapangan pekerjaan, maka akan tercipta pengangguran (Sulistiawati, 2012).

Tenaga kerja dapat dijadikan tolok ukur keberhasilan pembangunan suatu daerah, maksudnya penyerapan tenaga kerja mendukung keberhasilan pembangunan nasional secara keseluruhan. Suatu daerah dapat dikatakan maju apabila ditunjang dari segi pengetahuan masyarakat yang tinggi, adanya sumberdaya alam yang cukup memadai yang dikelola oleh sumberdaya manusia yang berpotensi besar agar dapat mencapai kemajuan dalam pembangunan daerah. Salah satu indikasinya adalah minimnya pengangguran di daerah tersebut, suatu 
daerah dapat dikatakan mampu memanfaatkan sumberdaya manusianya apabila dapat menekan pengangguran untuk dapat masuk ke dalam sektorsektor perekonomiannya guna meningkatkan pembangunan daerah (Santoso, 2010).

Kabupaten Barito Selatan adalah kabupaten dengan mata pencarian Tabel 1. Penduduk Usia 15 Tahun ke Atas yang Bekerja Menurut Sektor di Kabupaten Barito Selatan, Tahun 2011 - 2015 (Jiwa)

\begin{tabular}{|c|c|c|c|c|c|c|c|}
\hline \multirow[b]{2}{*}{ No. } & \multirow[b]{2}{*}{ Sektor } & \multicolumn{5}{|c|}{ Tahun } & \multirow{2}{*}{$\begin{array}{l}\text { Rata- } \\
\text { rata } \\
\text { (Jiwa) }\end{array}$} \\
\hline & & 2011 & 2012 & 2013 & 2014 & 2015 & \\
\hline & Pertanian & 39.305 & 38.609 & 42.494 & 39.705 & 30.824 & 38.187 \\
\hline & Kontribusi (\%) & 63,27 & 64,91 & 71,33 & 63,96 & 53,75 & 63,52 \\
\hline & $\begin{array}{l}\text { Pertambangan, } \\
\text { Energi \& Kontruksi }\end{array}$ & 4.343 & 2.687 & 2.090 & 3.488 & 3.448 & 3.211 \\
\hline & Kontribusi (\%) & 6,99 & 4,52 & 3,51 & 5,62 & 6,01 & 5,34 \\
\hline & Industri & 445 & 850 & 893 & 621 & 3.090 & 1.179 \\
\hline & Kontribusi (\%) & 0,71 & 1,43 & 1,50 & 1,00 & 5,39 & 1,96 \\
\hline \multirow{2}{*}{4.} & Jasa & 18.027 & 17.332 & 14.093 & 18.265 & 19.984 & 17.540 \\
\hline & Kontribusi (\%) & 29,01 & 29,14 & 23,66 & 29,42 & 34,85 & 29,17 \\
\hline & Jumlah & 62.120 & 59.478 & 59.570 & 62.079 & 57.346 & 60.117 \\
\hline & Kontribusi (\%) & 100,00 & 100,00 & 100,00 & 100,00 & 100,00 & 100,00 \\
\hline
\end{tabular}

Sumber : Badan Pusat Statistik Kabupaten Barito Selatan, 2016

Berdasarkan Tabel 1 diketahui

bahwa pada tahun 2011 ke tahun 2012 terjadi penurunan tenaga kerja sektor pertanian sebesar 700 jiwa. Tahun 2013 terjadi peningkatan jumlah pekerja sebesar 3.885 jiwa. tahun 2014 kembali terjadi penurunan jumlah pekerja sektor pertanian sebesar 3.789 jiwa. tahun 2015 terjadi penurunan jumlah tenaga kerja sektor pertanian dalam jumlah yang cukup besar dan cukup signifikan yaitu sebesar 8.881 jiwa.

Fluktuasi tenaga kerja sektor pertanian di Kabupaten Barito Selatan terjadi selama lima tahun terakhir. Dengan demikian sangat perlu diperhatikan apakah pertumbuhan kesempatan kerja di Kabupaten ini termasuk cepat atau sebaliknya. penduduk didominasi oleh sektor pertanian. Rentang tahun 2011-2015 sektor pertanian adalah sektor yang paling unggul. Jumlah penduduk yang bekerja pada sektor pertanian terus berfluktuasi setiap tahunnya, untuk mengetahui perkembangan pekerja di Kabupaten Barito Selatan dapat dilihat pada Tabel 1. 
Berdasarkan uraian dari latar belakang yang telah dikemukakan sebelumnya, maka tujuan penelitian ini adalah untuk mengetahui pertumbuhan kesempatan kerja di sektor pertanian di Kabupaten Barito Selatan tahun 20112015.

Hasil penelitian ini sangat diharapkan dapat berguna dalam menambah wawasan berkaitan dengan topik penelitian dan mengetahui lebih mendalam mengenai keadaan tenaga kerja disektor pertanian di Kabupaten Barito Selatan. Selain itu diharapkan pemerintah dapat menerima hasil penelitian ini sebagai sumbangan pemikiran dan bahan pertimbangan pengambilan kebijakan dalam perencanaan tenaga kerja, khususnya tenaga kerja di sektor pertanian.

\section{METODE PENELITIAN}

Penelitian ini dilaksanakan Kabupaten Barito Selatan dan dipilih secara purposive (sengaja). Data yang digunakan dalam penelitian ini adalah data sekunder dengan rentang waktu lima tahun, yaitu tahun 2011-2015 yang diperoleh dari Badan Pusat Statistik (BPS) Kabupaten Barito Selatan, Badan Pusat Statistik (BPS) Provinsi Kalimantan Tengah dan Dinas Ketenagakerjaan dan Transmigrasi (Disnakertrans) Kabupaten Barito Selatan. Data tersebut berupa data PDRB Kabupaten Barito Selatan, data tenaga kerja Kabupaten Barito Selatan, data tenaga kerja Provinsi Kalimantan Tengah, kondisi umum Kabupaten Barito Selatan, dan data lain yang mendukung.

Adapun untuk menganalisis Pertumbuhan Kesempatan Kerja Sektor Pertanian Kabupaten Barito Selatan menggunakan rumus Shift Share. Secara matematik dapat dapat dinyatakan sebagai berikut:

$$
\begin{aligned}
& \Delta Y i j \quad=P N i j+P P i j+P P W i j \\
& Y^{\prime} i j-Y i j=\Delta Y i j=Y i j(R a-1)+ \\
& \text { Yij }(\mathrm{Ri}-\mathrm{Ra})+\mathrm{Yij}(\mathrm{ri}-\mathrm{Ri}) \\
& \text { Dimana: } R a=Y^{\prime} / Y \\
& \mathrm{Ri}=\mathrm{Y}^{\prime} \mathrm{i} / \mathrm{Yi} \\
& \text { ri }=Y^{\prime} \mathrm{ij} / \mathrm{Yij}
\end{aligned}
$$

Keterangan :

PK : komponen pertumbuhan

Kabupaten Barito Selatan

PP : komponen pertumbuhan proporsional

PPW : komponen pertumbuhan pangsa wilayah

Y : kesempatan kerja total

Provinsi Kalimantan Tengah 2011

Y' : kesempatan kerja total

Provinsi Kalimantan Tengah 2015

Yi : kesempatan kerja sektor pertanian Provinsi Kalimantan Tengah tahun 2011

Y'i : kesempatan kerja sektor pertanian Provinsi Kalimantan Tengah tahun 2015

$\Delta Y i j \quad$ : pertumbuhan dalam kesempatan kerja sektor pertanian Kabupaten Barito Selatan

Yij : kesempatan kerja di sektor pertanian Kabupaten Barito Selatan pada tahun dasar analisis (tahun 2011)

$Y^{\prime}$ ij : kesempatan kerja di sektor pertanian Kabupaten Barito Selatan tahun akhir analisis (tahun 2015)

$(\mathrm{Ra}-1)$ : persentase perubahan kesempatan kerja yang 


\begin{tabular}{|c|c|}
\hline \multirow[b]{3}{*}{$(\mathrm{Ri}-\mathrm{Ra})$} & disebabkan \\
\hline & $\begin{array}{l}\text { komponen pertumbuhan } \\
\text { nasional }\end{array}$ \\
\hline & persentase perubahan \\
\hline \multirow{5}{*}{$(\mathrm{ri}-\mathrm{Ri})$} & $\begin{array}{l}\text { kesempatan kerja yang } \\
\text { disebabkan }\end{array}$ \\
\hline & $\begin{array}{l}\text { komponen pertumbuha } \\
\text { proporsional }\end{array}$ \\
\hline & persentase perubaha \\
\hline & $\begin{array}{ll}\text { kesmpatan kerja yar } \\
\text { disebabkan }\end{array}$ \\
\hline & $\begin{array}{l}\text { komponen pertumbuh } \\
\text { pangsa wilayah }\end{array}$ \\
\hline
\end{tabular}

Kriteria :

Apabila PPij $<0$ berarti pertumbuhan kesempatan kerja sektor pertanian Kabupaten Barito Selatan lambat, sedangkan apabila PPij > 0 berarti pertumbuhan kesempatan kerja sektor pertanian Kabupaten Barito Selatan cepat. Apabila PPWij > 0, pertumbuhan kesempatan kerja sektor pertanian Kabupaten Barito Selatan mempunyai daya saing yang baik apabila dibandingkan dengan sektor pertanian di wilayah lain, sedangkan apabila PPWij < 0 , maka berarti kesempatan kerja sektor pertanian Kabupaten Barito Selatan tidak dapat bersaing dengan baik apabila dibandingkan dengan sektor pertanian di wilayah lainnya.

Dari penjumlahan komponen pertumbuhan proporsional dan komponen pertumbuhan pangsa wilayah, dapat diperoleh nilai pergeseran bersih (PB) yang digunakan untu mengidentifikasi pertumbuhan kesempatan kerja sektor pertanian Kabupaten Barito Selatan. Pergeseran bersih dinyatakan dengan rumus: PBij $=$ PPij + PPWij
Dimana :

PBij adalah pergeseran bersih kesempatan kerja sektor pertanian Kabupaten Barito Selatan Kriteria:

PBij $\geq 0$, maka pertumbuhan kesempatan kerja sektor pertanian Kabupaten Barito Selatan termasuk ke dalam kelompok progresif (maju) PBij < 0, maka pertumbuhan kesempatan kerja sektor pertanian Kabupaten Barito Selatan termasuk ke dalam kelompok lamban

Pergeseran bersih juga dapat digunakan sebagai untuk melihat pengaruh tenaga kerja atau kesempatan kerja yang terjadi di Kabupaten Barito Selatan. Dimana apabila PPij > PPWij, berarti faktor eksternal yang lebih berpengaruh dan jika nilai PPij < PPWij berarti faktor lokasional yang lebih berpengaruh.

\section{HASIL DAN PEMBAHASAN}

Analisis Pertumbuhan Kesempatan Kerja Sektor Pertanian dan Sektor Ekonomi Lainnya

a. Analisis Pertumbuhan Kesempatan Kerja Sektor Pertanian

Penelitian ini hanya meneliti sektor pertanian di Kabupaten Barito Selatan. Sektor perekonomian lainnya hanya digunakan sebagai pembanding. Pertumbuhan kesempatan kerja sektor pertanian dilihat dari komponenkomponen pertumbuhnannya dianalisis dengan menggunakan analisis Shift Share. Hasil analisis nilai pertumbuhan kesempatan kerja dapat dilihat pada Tabel 2.

Tabel 2. Komponen Pertumbuhan Kesempatan Kerja Sektor Pertanian Kabupaten Barito Selatan 


\begin{tabular}{llcc}
\hline No. & \multicolumn{1}{c}{ Komponen Pertumbuhan } & $\begin{array}{c}\text { Nilai } \\
(\text { Jiwa })\end{array}$ & $\begin{array}{c}\text { Persentase } \\
(\%)\end{array}$ \\
\hline 1. & Pertumbuhan Kabupaten (PKij) & $3.873,979$ & 9,86 \\
2. & Pertumbuhan Proporsional (PPij) & $-6.646,790$ & $-16,92$ \\
3. & Pertumbuhan Pangsa Wilayah (PPWij) & $-5.708,189$ & $-14,52$ \\
4. & Pertumbuhan Kesempatan Kerja $(\Delta$ Yij) & -8.481 & -22 \\
5. & Pergeseran Bersih (PBij) & $-12.354,979$ & $-41,43$ \\
\hline
\end{tabular}

Sumber: Diolah dari data sekunder

Berdasarkan hasil dari analisis

Shift Share dapat diketahui bahwa kesempatan kerja sektor pertanian di Kabupaten Barito Selatan tahun 20112015 adalah sebagai berikut :

Komponen pertumbuhan nasional adalah perubahan kesempatan kerja/produksi dalam suatu wilayah yang disebabkan oleh perubahan kesempatan kerja atau produksi nasional secara umum. Bila diasumsikan bahwa tidak terdapat perbedaan karakteristik ekonomi antar sektor dan wilayah kurang lebih sama dan setiap sektor dan wilayah akan berubah dan bertumbuh dengan laju yang hampir sama dengan laju pertumbuhan nasional. Pertumbuhan nasional atau pertumbuhan provinsi Kalimantan Tengah dari analisis shift share diperoleh hasil perhitungan sebesar 3.873,979 atau sebesar 9,86\%. Hal ini berarti terjadi peningkatan sebesar 3.873 jiwa.

Komponen pertumbuhan proporsional Kabupaten Barito Selatan melalui perhitungan analisis shift share diperoleh hasil sebesar $-6.646,790$ apabila dipersentasikan adalah sebesar $16,92 \%$. Berdasarkan kriteria apabila PPij < 0 berarti pertumbuhan kesempatan kerja sektor pertanian Kabupaten Barito Selatan lambat, sedangkan apabila PPij $>0$ berarti pertumbuhan kesempatan kerja sektor pertanian Kabupaten Barito Selatan cepat. Kesempatan kerja sektor pertanian di Kabupaten Barito Selatan dibandingkan sektor lain adalah menurun sejumlah 6.646 jiwa, oleh karena itu maka dapat disimpulkan bahwa pertumbuhan kesempatan kerja sektor pertanian Kabupaten Barito Selatan termasuk kedalam kelompok lambat.

Komponen pertumbuhan pangsa wilayah Kabupaten Barito Selatan melalui perhitungan analisis shift share diperoleh hasil sebesar -5.708,189 apabila dipersentasekan yaitu sebesar $14,52 \%$. Berdasarkan kriteria apabila PPWij < 0, maka berarti kesempatan kerja sektor pertanian Kabupaten Barito Selatan tidak dapat bersaing dengan baik apabila dibandingkan dengan sektor pertanian di wilayah lainnya. Komponen pangsa wilayah tersebut menunjukkan bahwa terjadi perubahan kesempatan kerja sektor pertanian Kabupaten Barito Selatan yang jika dibandingkan dengan sektor pertanian wilayah lain yaitu terjadi penurunan sebesar 5.708 jiwa. Hasil perhitungan tersebut dapat diketahui bahwa komponen pertumbuhan pangsa wilayah Kabupaten Barito Selatan adalah negatif dan kurang dari 0, hal ini berarti bahwa kesempatan kerja sektor pertanian Kabupaten Barito Selatan tidak dapat bersaing dengan baik apabila dibandingkan dengan sektor pertanian di wilayah lain.

Pertumbuhan kesempatan kerja sektor pertanian Kabupaten Barito Selatan tahun 2011-2015 menunjukkan hasil sebesar -8.481 yang apabila dipersentasekan $-22 \%$. Hasil analisis 2011-2015 ini berarti terjadi penurunan 
kesempatan kerja di sektor pertanian sebesar 8.481 jiwa. Pertumbuhan kesempatan kerja sektor pertanian Kabupaten Barito Selatan mengalami penurunan, sedangkan sektor perekonomian lainnya meningkat kecuali sektor pertambangan, energi dan kontruksi. Hal ini berarti banyak tenaga kerja sektor pertanian beralih ke sektor perekonomian lainnya, namun walaupun demikian sektor pertanian tetap menjadi sektor yang memiliki kemampuan menyerap tenaga kerja lebih besar. Hal ini berarti peranan sektor pertanian dalam menyerap tenaga kerja masih dapat diperhitungkan walaupun kecil pertumbuhannya.

Komponen pergeseran bersih dapat digunakan untuk mengidentifikasi pertumbuhan kesempatan kerja pada suatu wilayah pada masing-masing sektor perekonomian, sehingga dapat ditentukan apakah sektor tersebut termasuk dalam kelompok yang progresif (maju) atau masuk dalam kelompok pertumbuhan lambat. Nilai PBij diperoleh melalui penjumlahan atau PPij ditambah PPWij. Hasil analisis menunjukkan bahwa pergeseran bersih Kabupaten Barito Selatan adalah sebesar -12.354,979 apabila dipersentasekan yaitu sebesar $-41,43 \%$. Dilihat dari kriteria yang menunjukkan apabila PBij $\geq 0$, maka pertumbuhan kesempatan kerja sektor pertanian Kabupaten Barito Selatan termasuk ke dalam kelompok progresif (maju). PBij < 0 , maka pertumbuhan kesempatan kerja sektor pertanian Kabupaten Barito Selatan termasuk ke dalam kelompok lamban. Dilihat dari nilai pergeseran bersih yang hasilnya negatif maka dapat diketahui bahwa pertumbuhan kesempatan kerja sektor pertanian Kabupaten Barito Selatan termasuk ke dalam kelompok lamban. Dari hasil perhitungan nilai PPij $<$ PPWij yaitu sebesar $-6.646,790<-$
$5.708,189$ hal ini berarti faktor lokasional yang lebih berpengaruh terhadap pergeseran bersih kesempatan kerja sektor pertanian Kabupaten Barito selatan.

Penelitian ini menunjukkan pertumbuhan kesempatan kerja yang hasilnya negatif atau tergolong ke dalam kelompok lambat. Hasil dari penelitian ini tidak jauh berbeda dengan penelitian Kurniawan (2008) yang berjudul "Peranan Sektor Pertanian dalam Penyerapan Tenaga Kerja di Kabupaten Temanggung”. Dalam penelitian Kurniawan nilai komponen pertumbuhan nasional (PN) sebesar 7.967,603. Nilai PN yang positif diperoleh karena adanya kebijakan nasional yang menguntungkan bagi sektor pertanian. Seperti adanya kebijakan harga gabah, pemberian subsidi input pertanian pada pupuk dan benih serta adanya penyuluhan pertanian yang terus berlangsung. Komponen pertumbuhan proporsional (PP) sebesar 33.508,559. Nilai PP ini dipengaruhi permintaan produk akhir pertanian dan ketersediaan bahan mentah. Selain itu adanya alih fungsi lahan pertanian ke non pertanian yang menyebabkan penurunan luas panen sehingga menurunkan jumlah produksi dan adanya ketertarikan penduduk untuk bekerja disektor non pertanian. Nilai komponen pertumbuhan pangsa wilayah sebesar -63.214,044. Hal ini disebabkan kurangnya daya saing seperti kurangnya keunggulan komparatif, akses pasar yang sulit, kurangnya dukungan lembaga dan terbatasnya prasarana sosial ekonomi. Dari penjumlahan PP dan PPW maka diperoleh nilai pergeseran bersih (PB) sebesar -96.722,603 dengan nilai pertumbuhan kesempatan kerja $-34,73 \%$ yang berarti sektor pertanian tumbuh secara lambat sehingga akan 
perekonomian yang pertumbuhannya lebih progresif (maju) adalah sektor jasa yaitu sebesar 4.555,137 atau apabila dipersentasekan sebesar $25,27 \%$. Hal ini berarti jika terjadi pertumbuhan kesempatan kerja sektor jasa di Kabupaten Barito Selatan maka akan terjadi peningkatan sebesar 4.555 jiwa.

Berdasarkan

komponen

pertumbuhan pangsa wilayah, sektor industri adalah satu-satunya sektor yang bernilai positif dengan nilai sebesar 2.476,658 atau sebesar 556,55 \% . Apabila terjadi perubahan kesempatan kerja di sektor tersebut di Kabupaten Barito Selatan jika dibandingkan dengan sektor yang sama di wilayah lain terjadi peningkatan sebesar 2.476 jiwa. Sektor industri mampu bersaing dengan baik dengan sektor di wilayah lain. Sedangkan sektor pertanian, pertambangan, energi dan kontruksi, dan jasa merupakan sektor yang bernilai negatif yaitu sektor pertanian sebesar $5.708,185$ atau $-14,52 \%$, sektor pertambangan, energi dan kontruksi sebesar $-1.827,452$ atau $-42,08 \%$, dan sektor jasa sebesar -4.374,915 atau $24,27 \%$. Apabila terjadi perubahan kesempatan kerja di masing-masing sektor tersebut di Kabupaten Barito Selatan jika dibandingkan dengan sektor yang sama di wilayah lain terjadi penurunan sebesar 5.708, 1.827 dan 4,374 jiwa. Ketiga sektor ini tidak mampu bersaing dengan baik dengan sektor di wilayah lain.

Pergeseran bersih digunakan untuk mengidentifikasi pertumbuhan kesempatan kerja sektor pertanian Kabupaten Barito Selatan. Nilai pergeseran bersih diperoleh melalui penjumlahan dari PPij dan PPWij. Berdasarkan sektor perekonomian Kabupaten Barito Selatan sektor industri dan sektor jasa adalah sektor yang bernilai positif atau progresif (maju). Sedangkan sektor pertanian dan sektor pertambangan, energi dan kontruksi bernilai negatif atau lamban.

\section{Kesimpulan}

\section{KESIMPULAN}

Berdasarkan hasil penelitian Peranan Penyerapan Tenaga Kerja dan Proyeksi Kesempatan Kerja Sektor Pertanian di Kabupaten Barito Selatan tahun 2011-2015 diketahui bahwa pertumbuhan kesempatan kerja sektor pertanian Kabupaten Barito Selatan tahun 2011-2015 dengan menggunakan analisis shift share menunjukkan hasil sebesar -8.481 yang apabila dipersentasekan -22 \%. Hasil analisis 2011-2015 ini berarti terjadi penurunan kesempatan kerja di sektor pertanian sebesar 8.481 jiwa. Kesempatan kerja sektor pertanian Kabupaten Barito Selatan masuk ke dalam kelompok lamban.

\section{DAFTAR PUSTAKA}

Arsyad. L. 2009. Angkatan Kerja, Pengantar Perencanaan Dan Dan Pembangunan Ekonomi Daerah Edisi Kedua Cetakan Pertama. BPFE UGM. Yogyakarta.

Badan Pusat Statistik. 2013. Kabupaten Barito Selatan Dalam Angka Tahun 2012. BPS Barito Selatan. Barito Selatan. 2014. Kabupaten

Barito Selatan Dalam Angka Tahun 2013

BPS Barito Selatan. Barito

Selatan. .2015. Kabupaten Barito Selatan Dalam Angka Tahun 2014

BPS Barito Selatan. Barito Selatan.

.2016. Kabupaten

Barito Selatan Dalam Angka Tahun 2015

BPS Barito Selatan. Barito Selatan. 
Badan Pusat Statistik. 2013. Statistik Ketenagakerjaan 2012. BPS Kalimantan Tengah. Kalimantan Tengah.

\section{. 2014. Statistik}

Ketenagakerjaan 2013. BPS Kalimantan

Tengah. Kalimantan Tengah . . 2015. Statistik Ketenagakerjaan 2014. BPS Kalimantan Tengah. Kalimantan Tengah. . 2016. Statistik Ketenagakerjaan Tahun 2015. BPS Kalimantan Tengah. Kalimantan Tengah.

Budiharsono. S. 2005. Teknik Analisis Pembangunan Wilayah Pesisir Dan Lautan. Pradnya Paramita. Jakarta.

Faqih, A. 2009. Pengaruh Pembangunan Sektor Pertanian Terhadap Kesempatan Kerja dan Distribusi Pendapatan di Provinsi Jawa Tengah. Skripsi. Fakultas Ekonomi Universitas Negeri Semarang. Semarang.

Kurniawan, A. 2008. Peranan Sektor Pertanian dalam Penyerapan Tenaga Kerja di Kabupaten Temanggung. Skripsi. Fakultas Pertanian Universitas Sebelas Maret. Surakarta.

Luthfi, M. K. 2017. Peran Sektor Pertanian terhadap Penyerapan Tenaga Kerja dan Distribusi Pendapatan di Kabupaten Klaten. Skripsi. Fakultas Pertanian Universitas Sebelas Maret. Surakarta.

Nugroho, F. A. 2015. Peranan Sektor Pertanian dalam Penyerapan
Tenaga Kerja di Kabupaten Kebumen. Skripsi. Fakultas Pertanian Universitas Sebelas Maret. Surakarta.

Rozi, T. F., Sofyan, Marsudi, E. 2017. Peranan Sektor Pertanian dalam Penyerapan Tenga Kerja di Provinsi Aceh. Jurnal Ilmiah Mahasiswa Pertanian Unsyiah 2 (2).

Safangatun, F. I. 2011. Peranan Sektor Pertanian dalam Penyerapan Tenaga Kerja di Kabupaten Cilacap. Skripsi. Fakultas Pertanian Universitas Sebelas Maret. Surakarta.

Safira, E. 2017. Analisis Peranan Sektor Pertanian dalam Penyerapan Tenaga Kerja di Kabupaten Sukoharjo. Skripsi. Fakultas Pertanian Universitas Sebelas Maret. Surakarta.

Santoso. 2010. Peranan Sektor Pertanian dalam Penyerapan Tenaga Kerja di kabupaten Wonogiri. Skripsi. Fakultas Pertanian Universitas Sebelas Maret. Surakarta.

Soekartawi. 1996. Pembangunan Pertanian untuk Mengentaskan Kemiskinan. UI Press. Jakarta.

Sulistiawati, R. 2012. Pengaruh Upah Minimum Terhadap Penyerapan Tenaga Kerja dan Kesejahteraan Masyarakat di Provinsi di Indonesia. Jurnal EKSOS Volume 08 No. 3, hal 195 - 211.

Tarigan, R. 2014. Ekonomi Regional. Teori dan Aplikasi.Bumi Aksara.Jakarta.

Todaro M. P. 2000. Pembangunan ekonomi di dunia ke tiga: jilid 1. Erlangga. Jakarta. 